\title{
Chromosomes of Girella laevifrons (Tschudi 1846) (Osteichthyes: Kyphosidae)
}

\section{Cromosomas de Girella laevifrons (Tschudi 1846) (Osteichthyes: Kyphosidae)}

\author{
Irma Northland-Leppe ${ }^{1}$, Drina Véjar ${ }^{1}$, Pedro Jara-Seguel $^{2 *}$, Nelson Fuentes ${ }^{1} \&$ Cristian Núñez $^{1}$ \\ ${ }^{1}$ Departamento Biomédico, Facultad de Ciencias de la Salud, Universidad de Antofagasta, Casilla 170, Antofagasta-Chile. \\ ${ }^{2}$ Escuela de Ciencias Ambientales, Facultad de Recursos Naturales, Universidad Católica de Temuco, Casilla 15-D, Temuco- \\ Chile. \\ *E-mail: pjara@uct.cl
}

\begin{abstract}
RESUMEN
El número cromosómico y la morfología del cariotipo de Girella laevifrons (Tschudi 1846) son descritos por primera vez. G. laevifrons presenta un número cromosómico $2 \mathrm{n}=48$ y su cariotipo está constituido por 24 pares de cromosomas acrocéntricos en ambos sexos, similar a lo documentado previamente para otras especies del género Girella Gray, 1835.
\end{abstract}

\begin{abstract}
The chromosome number and karyotype morphology of Girella laevifrons (Tschudi 1846) are described for the first time. $G$. laevifrons presents a chromosome number of $2 n=48$ and its karyotype is formed in both sexes by 24 acrocentric chromosome pairs, similar to what has been described for other species of Girella Gray, 1835.
\end{abstract}

Girella laevifrons (Tschudi 1846) is an abundant fish species distributed in the Pacific coast and islands from Guañape in Perú to El Tabo in Chile $\left(8^{\circ} \mathrm{S}\right.$ to $33^{\circ} \mathrm{S}$; Pequeño \& Sáez 2008). At present, genetic studies on $G$. laevifrons are not available and basic aspects, such as chromosome number and karyotype structure, remain unknown. The lack of genetic studies on $G$. laevifrons contrasts with the varied systematics research centered in other species of Girella, which include information on karyotypes, C and Ag-NOR banding, allozyme electrophoresis, PCR-RFLP markers, and gene sequences (Hinegardner \& Rosen 1972, Ueno \& Ojima 1991, Yagishita et al. 2002, Matsuoka 2002, Hardie \& Hebert 2004, Itoi et al. 2007, Saito et al. 2008). The characterization of karyotype changes (e.g., numerical and/or structural) among related fish species is important to understand processes of genetic variation, genome evolution and speciation, as well as to delimit taxa (Winkler et al. 2004).

Here we describe for the first time the karyotype morphology of $G$. laevifrons and compare it with that already reported for other species of the genus.

Ten specimens including five males and five females of $G$. leavifrons were collected at the Pacific coast in a beach located in front of the Universidad de Antofagasta, San Jorge Bay, Chile $\left(23^{\circ} 42^{\prime} \mathrm{S} ; 70^{\circ} 26^{\prime} \mathrm{W}\right)$. The cytological protocol described by Northland-Leppe et al. (2009) was followed. Chromosomes were measured in photomicrographic enlargements of ten metaphases. The karyotype was made up with the chromosomes ordered on the basis of decreasing length.

Male and female individuals of $G$. laevifrons showed a diploid chromosome number $2 \mathrm{n}=48$ ( $\mathrm{NF}=48)$; the karyotype is composed only by acrocentric chromosomes (Fig. 1). Chromosomes are small (length $<4.0 \mu \mathrm{m}$ ). Chromosomes lack secondary constriction and satellites. Sex chromosomes were not identified using conventional Giemsa staining.

Resemblance in chromosome number and karyotype morphology was observed among $G$. laevifrons and the Japanese species G. melanichthys Richardson, 1846 and G. punctata Gray, 1835 (Nishikawa \& Karasawa 1972, Ueno \& Ojima 1991). However, conspicuous secondary constrictions co-localized with Ag-NOR bands in one pair of large chromosomes described in kidney cells of G. melanichthys (Ueno \& Ojima 1991) were not observed in chromosomes of $G$. laevifrons obtained from gill cells. The absence of secondary constrictions in $G$. laevifrons may be due to technical artefacts, or by the existence of functional differences of ribosomal genes among different tissues of different species (Sánchez et al. 1990). The use 
of Fluorescence in situ hybridization aimed to locate rDNA would help clarify this issue.

The karyotype resemblance among species of Girella is remarkable and can also be extended to species of Kyphosus Lacepede, 1801 (Table I). Karyological resemblance between these two genera of the family Kyphosidae is also seen in DNA C-values. C-values of Girella fall within the range documented for Kyphosus and other genera of Kyphosidae (Table I). These genome similarities (i.e., chromosome number and morphology, DNA C-values), although partial, support the close relationship among Girella and Kyphosus previously proposed by Yagishita et al. (2002) based on molecular phylogenies. Interestingly, G. mezina Jordan \& Starks, 1907 and G. punctata Gray, 1835 included in that same phylogeny appeared as very close species, which is consistent with the karyotype resemblances discussed in the present work.

Finally, despite recent advances on genetic studies in Girella species, several issues remain unclear. Additional research using conventional and/or molecular cytogenetic techniques

\section{an an da na acon on an}
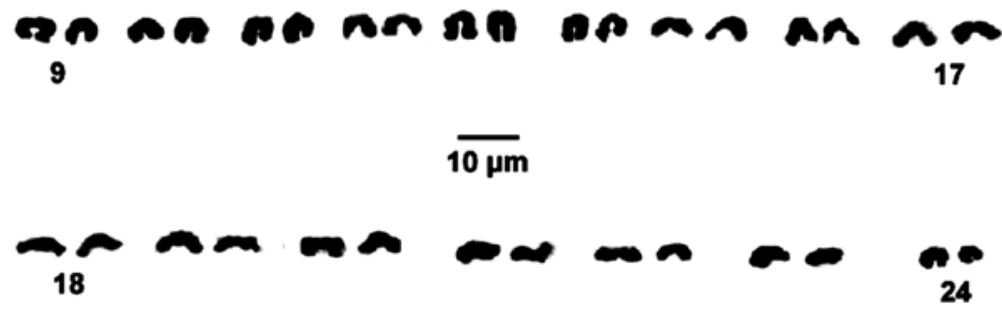

FIGURE 1. Karyotype of Girella laevifrons, $2 \mathrm{n}=48$.

FIGURA 1. Cariotipo de Girella laevifrons, $2 \mathrm{n}=48$.

TABLE I. Cytogenetic characters of species of Kyphosidae from Chile and Japan. 2n, somatic chromosome number; FN, arms fundamental number; L, largest chromosome length; S, shortest chromosome length; $\mathrm{CV}(\mathrm{pg})$, haploid DNA content in picograms (C-value).

Tabla I. Caracteres citogenéticos de especies de Kyphosidae de Chile y Japón. 2n, Número cromosómico somático; FN, número fundamental de brazos; L, longitud del cromosoma más largo; S, longitud del cromosoma más corto; CV(pg), contenido de ADN haploide en picogramos (valor C).

\begin{tabular}{|c|c|c|c|c|c|}
\hline Species & $2 n$ & FN & $\mathrm{CV}(\mathrm{pg})$ & Haploid karyotype formula & References \\
\hline Girella laevifrons (Tschudi 1846) & 48 & 48 & - & 24 acrocentric & Present study \\
\hline G. melanichthys Richardson, 1846 & 48 & 48 & - & 24 acrocentric & Ueno \& Ojima (1991) \\
\hline G. punctata Gray, 1835 & 48 & - & - & - & Nishikawa \& Karasawa 1972) \\
\hline G. nigricans Ayres, 1860 & - & - & 1.10 & - & Hinegardner \& Rosen (1972) \\
\hline G. tricuspidata Quoy \& Gaimard, 1824 & - & - & 0.90 & - & Hardie \& Hebert (2004) \\
\hline Kyphosus sp. Lacepède, 1801 & 48 & 50 & - & 1 submetacentric, 23 acrocentric & Takai \& Ueno (1997) \\
\hline K. lembus (Cuvier, 1831) & 48 & 50 & - & 1 submetacentric, 23 acrocentric & Takai \& Ueno (1997) \\
\hline K. cinerascens (Forsskal, 1775) & 48 & 50 & - & 1 submetacentric, 23 acrocentric & Takai \& Ueno (1997) \\
\hline K. bigibbus Lacepède, 1801 & 48 & - & 0.87 & - & Ojima \&Yamamoto (1990) \\
\hline Labracoglossa argentiventris Peters, 1866 & - & - & 0.90 & - & Ojima \& Yamamoto (1990) \\
\hline Medialuna californiensis (Steindachner, 1876) & - & - & 0.81 & - & Hinegardner \& Rosen (1972) \\
\hline Scorpis lineolatus Kner, 1865 & - & - & 1.06 & - & Hardie \& Hebert (2004) \\
\hline
\end{tabular}


could be applied to study G. laevifrons and insular Chilean species of Girella (e. g., G. albostriata Steindachner, 1898; G. feliciana Clark, 1938; G. nigricans) (Pequeño \& Sáez 2000). These studies would allow envisaging mechanisms of karyotype evolution within the genus. Advances in this field have been documented by Takai \& Ueno (1997) for species of the genus Kyphosus in which some characters (e. g. chromosome number and morphology, Ag-NOR location, some C-bands) are conserved and perhaps have been retained from the common ancestor of the group, whereas karyotype modification would be mainly caused by amplification of constitutive heterochromatin.

\section{ACKNOWLEDGEMENTS}

Our thanks to two anonymous reviewers for their comments.

\section{BIBLIOGRAPHY}

Hardie, D. \& P. Hebert. 2004. Genome-size evolution in fishes. Canadian Journal of Fisheries and Aquatic Science 61: 1636-1646.

Hinegardner, R. \& D. Rosen. 1972. Cellular DNA content and the evolution of teleostean fishes. American Naturalist 106: 621-644.

Itoi, S., T. Saito, S. Washio, M. Shimojo, N. Takai, K. Yoshihara \& H. Sugita. 2007. Speciation of two sympatric coastal fish species, Girella punctata and Girella leonina (Perciformes, Kyphosidae). Organisms Diversity \& Evolution 7:12-19.

MatsuOKA, N. 2002. Molecular phylogeny and allozymes variation of the five common fish of the suborder Percoidei. Bulletin of the Facultad of Agriculture \& Life Science, Hirosaki University 5: 17-22.

Nishikawa, S. \& T. Karasawa. 1972. A comparative study of chromosomes in Japanese fishes. I. A study of two somatic chromosomes of three species of Scups. Journal Shimonoseki University of Fisheries 20(3):101-105.

Northland-Leppe, I., N. Lam, P. Jara-Seguel \& J. Capetillo-Arcos. 2009. Chromosomes and Ag-NOR location in fluviate populations of Salmo trutta fario L. 1758 (Salmoniformes: Salmonidae) from Atacama Desert, Chile. Gayana 73(1): 45-48.

Оліма, Y. \& K. Yамамото. 1990. Cellular DNA contents of fishes determined by flow cytometry. La Kromosomo II 57: 1871-1888.

Pequeño, G. \& S. SÁez. 2000. Los peces litorales del Archipiélago de Juan Fernández (Chile): Endemismo y relaciones ictiogeográficas. Investigaciones Marinas 28: 27-37.

Pequeño, G. \& S. SÁez. 2008. El estatus taxonómico de Doydixodon laevifrons (Tschudi, 1846) (Osteichthyes: Kyphosidae). Revista Peruana de Biología 15(1): 101-104.

Saito, T., S. Washio, K. Dairiki, M. Shimojo, S. Itor \& H. Sugita. 2008. High gene flow in Girella punctata (Perciformes, Kyphosidae) among the Japanese Islands inferred from partial sequence of the control region in mitochondrial DNA. Journal of Fish Biology 73: 1937-1945.

SÁnchez, L., P. Martínez, P. Viñas \& Bouza. 1990. Analysis of the structure and variability of nucleolar organizer regions of Salmo trutta by $\mathrm{C}, \mathrm{Ag}$ and restriction endonuclease banding. Cytogenetic Cell Genetic 54: 6-9.

TAKaI, A. \& K. Ueno. 1997. Karyotypes and chromosomal distribution of constitutive heterochromatin and nucleolus organizer regions in three kyphosid fish (Perciformes). Cytobios 89: 141-148.

Ueno, K. \& Y. OлIma. 1991. Notes on the chromosomes of Girella melanichthys and Lutjanus russelli (Pisces, Perciformes). Chromosome Information Service, 52: 3-5.

Winkler, F., D. Garcia-Melys \& C. Palma-Rojas. 2004. Karyotypes of three South East Pacific flounder species of the family Paralichthyidae. Aquaculture Research 35: 1295-1298.

Yagishita, N., T. Kobayashi \& T. Nakabo. 2002. Review of monophylia of the Kyphosidae (sensu Nelson, 1994), inferred from mitochondrial ND2 gene. Ichthyological Research 49: 103-108.

Recibido: 12.05 .10

Aceptado: 09.09.10 